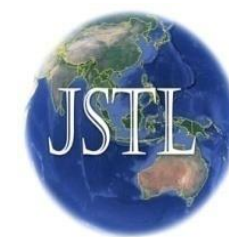

\title{
Kajian Sifat Kuantitatif Galur F2 Tanaman Jagung di Lahan Kering
}

\section{Study of the Quantitative Characteristics of the F2 Line of Corn Plants on dry land}

\author{
I Wayan Sudika*, I Wayan Sutresna, Dwi Ratna Anugrahwati, Lestari Ujianto \\ Program Studi Agroekoteknologi Jurusan Budidaya Pertanian Fakultas Pertanian Unram \\ *corresponding author,email: sudikawayanms@gmail.com
}

Manuscript received: 24-11-2021. Accepted: 21-12-2021:

\begin{abstract}
ABSTRAK
Penelitian ini ditujukan untuk mengetahui rata-rata sudut daun, daya hasil dan umur panen pada setiap galur F2 dibandingkan kedua tetua masing-masing. Selain itu, ingin diketahui pula nilai koefisien keragaman genetik dan heritabilitas ketiga sifat tersebut. Percobaan dirancang dengan rancangan acak kelompok dengan jumlah perlakuan sebanyak 20 populasi, yaitu 16 galur F2 dan 4 tetua. Setiap perlakuan diulang sebanyak $3 \mathrm{kali}$, sehingga diperoleh 60 unit percobaan. Data hasil percobaan, dianalisa dengan analisis sidik ragam pada taraf nyata 5 persen dan uji lanjut menggunakan uji Beda Nyata Terkecil (BNT) pada taraf nyata yang sama. Hasil penelitian menunjukkan, bahwa galur F2 P8IS x T1NK7328 (R16), F2 P8IS x T1NK7328 (R18), dan galur F2 P8IS x NK212 (R4), memiliki sudut daun tergolong sama dengan masing-masing tetua turunan pertama hibrida/hibrida (T1NK7328 dan NK212) dan lebih kecil dibanding Sinta Unram. Umur panen ketiga galur F2 tersebut tergolong super genjah. Daya hasil (bobot biji kering pipil per plot) galur F2 P8IS x T1NK7328 (R16), F2 P8IS x T1NK7328 (R18), sama dengan kedua tetua dan galur F2 P8IS x NK212 (R4), lebih tinggi dibanding Sinta Unram; namun sama dengan tetua hibrida (NK212). Daya hasil memiliki koefisien keragaman genetik tergolong tinggi; umur panen sedang dan sudut daun tergolong rendah. Heritabilitas arti luas tergolong tinggi diperoleh pada umur panen dan daya hasil; sedangkan sudut daun tergolong rendah. Ketiga galur F2 tersebut dapat digunakan sebagai bahan populasi dasar untuk kegiatan pemuliaan berikutnya.
\end{abstract}

Kata kunci: hibridisasi; Sinta Unram; daya hasil; sudut daun

\footnotetext{
ABSTRACT

This study was aimed to determine the average of leaf angle, yield and harvest age of each F2 line compared to the two parents respectively. In addition, we also want to evaluate the coefficient of genetic diversity and heritability of the three traits. The experiment was designed in a randomized block design with a total treatment of 20 populations, namely 16 F2 lines and 4 parents. Each treatment was repeated 3 times, so that 60 experimental units were obtained. The experimental data were analyzed by analysis of variance at the 5 percent significance level and further tests using the Least Significant Difference at the same significance level. The results showed that the F2 P8IS x T1NK7328 (R16), F2 P8IS x T1NK7328 (R18) lines, and the F2 P8IS x NK212 (R4) lines, had leaf angles same as each parent of
} 
the first hybrid/hybrid offspring (T1NK7328 and NK212) and smaller than the Sinta Unram. The harvest time of the three F2 lines was classified as super early. Yield (weight of dry seeds per plot) of F2 P8IS x T1NK7328 (R16), F2 P8IS x T1NK7328 (R18) lines, were the same as both parents and F2 P8IS x NK212 (R4) lines, higher than Sinta Unram; but the same as the hybrid parent (NK212). Coefficient of genetic diversity of yield is high; medium for harvest time and low for leaf angle. Heritability in broad sense is classified as high, obtained at harvest time and yield; while the heritability of leaf angle is low. The three F2 lines can be used as basic population material for subsequent breeding activities.

Key words: hybridization; Sinta Unram; yield; leaf angle

\section{PENDAHULUAN}

Populasi hasil seleksi massa dengan teknik indeks dasar hingga siklus kedelapan (P8IS) telah diuji di lahan kering. Hasil menunjukkan, bahwa umur panen populasi tersebut tergolong super genjah (< 80 hari); bersifat stay-green (rata-rata bobot brangkasan segar $391 \mathrm{~g} / \mathrm{tan}$ dengan 8-9 helai daun masih hijau saat panen) dengan rata-rata hasil 7,098 t/ha lebih tinggi dibanding varietas unggul Gumarang (Sudika et al., 2019). Populasi ini telah didaftarkan dengan nama Sinta Unram. Daya hasil populasi tersebut perlu ditingkatkan melalui kegiatan pemuliaan.

Peningkatan daya hasil masih dapat dilakukan melalui peningkatan potensi genetik dan memperkecil sudut daun. Sudut daun yang lebih kecil menunjukkan daun-daun lebih tegak, sehingga lebih efektif memanfaatkan cahaya matahari dan dapat ditanam lebih rapat (Jaya et al., 2019). Disisi lain, varietas hibrida beredar sekarang termasuk hibrida komersial dengan sudut daun kecil. Populasi P8IS telah hibridisasi secara resiprok masing-masing dengan Hibrida NK212, NK7328, dan Turunan pertama NK7328 guna memperoleh keturunan yang memiliki sudut daun lebih kecil dibanding P8IS, namun sifat-sifat P8IS tidak jauh berubah. Menurut Lupi (1995), hibridisasi bertujuan untuk menggabungkan karakter- karakter baik yang terdapat pada tanaman berbeda, menjadi satu genotipe baru. Perubahan sifat-sifat akibat hibridisasi tergantung dari besarnya perbedaan frekuensi allel berkenan kedua populasi yang disilangkan dan derajat dominansi (Reif et. al., 2007). Galur-galur F1 hasil hibridisasi telah dievaluasi untuk memberikan gambaran terhadap terjadinya kombinasi sifat-sifat pada F1 tersebut. Hasil penelitian menunjukkan bahwa sudut daun dan daya hasil F1 seluruh persilangan sama dengan masing-masing tetua; namun terdapat tiga hasil persilangan yang memiliki nilai heterosis sudut daun negatif tinggi, yaitu G15 sebesar -21.69\%; G26, -67.23\% dan G38 sebesar $36.15 \%$. Hal ini berarti, sudut daun galur F1 tersebut lebih kecil dibanding sudut daun P8IS. Daya hasil sebagian besar galur F1 cenderung meningkat dibandingkan dengan P8IS (Sudika dan Anugrahwati, 2020). Galur-galur F1 telah dibuat galur F2 dan telah diuji di lahan kering. Yunandra et al. (2017) menyatakan, bahwa keragaman tertinggi terdapat pada generasi F2 sehingga perlu diseleksi untuk memperoleh galur yang diharapkan. Temuan Romadhona et al. (2014) menunjukkan seleksi massa memberikan kemajuan genetik harapan tertinggi untuk karakter tinggi tanaman, tinggi kedudukan tongkol, dan diameter tongkol. Seleksi tongkol ke baris (ear to row) membuahkan kemajuan seleksi harapan tertinggi untuk panjang tongkol, bobot biji per tanaman, dan banyak biji per tanaman.

Keragaman genetik hasil hibridisasi perlu diukur secara kuantitatif. Berdasarkan asumsi, tidak ada korelasi genetik dengan lingkungan, maka ragam genetik, lingkungan dan interaksinya merupakan penyusun ragam fenotipe (Wardyn et al., 2007). Terjadinya keragaman 
genetik merupakan akibat perbedaan genotipe antar individu tanaman dalam populasi (Dahlan dan Slamet, 1992). Besarnya proporsi ragam genetik terhadap ragam fenotipik dinyatakan sebagai heritabilitas arti luas (H2) atau heritabilitas arti sempit (h2), apabila hanya ragam aditif yang diperhitungkan. Heritabilitas sangat tergantung dari tindak gen dan struktur genetik serta faktor lingkungan (Ujianto et al., 2020). Apabila h2 semakin tinggi; berarti semakin besar ragam genetik yang dapat dikaitkan dengan pengaruh tindak gen aditif, sehingga seleksi akan memberikan hasil yang memadai. Hasil penelitian Wannows et al. (2010), bahwa heritabilitas tergolong tinggi, diperoleh pada tinggi tanaman, indeks luas daun, tinggi tongkol, jumlah biji per baris, masak fisiologis, panjang tongkol, jumlah baris per tongkol dan diameter tongkol. Heritabilitas tergolong sedang diperoleh pada sudut daun (48\%), luas daun spesifik (46\%) dan bobot 100 butir biji (44\%). Heritabilitas tergolong rendah pada karakter hasil (39\%), umur keluar rambut tongkol (34\%), stay-green (27\%) dan bobot daun spesifik (26\%). Hasil penelitian Shahrokhi et al. (2013), bahwa heritabilitas arti luas jumlah daun, panjang tongkol, jumlah biji per baris, jumlah baris per tongkol, umur keluar malai, jumlah biji per tongkol, umur keluar rambut tongkol dan hasil berkisar antara 0.29-0.87; sedangkan heritabilitas arti sempit berkisar antara 0.02-0.51. Hasil penelitian Sudika et al. (2018), bahwa heritabilitas arti luas tergolong tinggi diperoleh pada jumlah daun per tanaman $(73.12 \%)$ dan bobot 1.000 butir biji $(64.19 \%)$. Daya hasil, panjang tongkol, diameter tongkol dan bobot tongkol kering panen, heritabilitasnya tergolong sedang berkisar antara 31.82 hingga $49.75 \%$ ).

\section{BAHAN DAN METODE}

Percobaan telah dilaksanakan di Desa Gumantar, kabupaten Lombok Utara pada tanah bertekstur pasiran. Kegiatan telah dimulai bulan Mei sampai dengan bulan September 2021. Bahan yang digunakan meliputi benih jagung hibrida NK212, hibrida NK7328, Turunan pertama NK7328, Sinta Unram dan galur-galur F2 sebanyak 16 galur. pupuk Phonska, pupuk Urea, herbisida Calaris 550 SC, Furadan 3G, dan Saromyl 35 SD.

Percobaan dirancang dengan Rancangan Acak Kelompok, terdiri atas 20 perlakuan dan diulang sebanyak 3 kali. Perlakuannya, meliputi G1, F2 P8IS x NK7328 (R6); G2, F2 P8IS x NK7328 (8); G3, F2 P8IS x NK7328 (R9); G4, F2 P8IS x NK7328 (R11); G5, F2 P8IS x NK7328 (14); G6, F2 P8IS x NK7328 (R14); G7, F2 P8IS x T1NK7328 (13); G8, F2 P8IS x T1NK7328 (R16); G9, F2 P8IS x T1NK7328 (R18); G10, F2 P8IS x T1NK7328 (19); G11, F2 P8IS x NK212 (R1); G12, F2 P8IS x NK212 (2); G13, F2 P8IS x NK212 (R3);G14, F2 P8IS x NK212 (R4); G15, F2 P8IS x NK212 (5); G16, F2 P8IS x NK212 (R5); G17, NK7328; G18, T1NK7328;G19, NK212 dan G20, Sinta Unram.

Sifat-sifat yang diamati, meliputi umur keluar malai, umur keluar rambut tongkol, umur panen, sudut daun, tinggi tanaman, jumlah daun per tanaman, diameter batang, jumlah daun segar saat panen per tanaman, bobot brangkasan segar per tanaman, bobot tongkol kering panen per tanaman, panjang tongkol,.diameter tongkol, daya hasil (bobot biji kering pipil per plot) dan bobot 1.000 butir biji.

Data hasil pengamatan dianalisa dengan analisis sidik ragam pada taraf nyata 5 persen. Berdasarkan hasil analisis ragam dihitung nilai koefisien keragaman genetik dan nilai heritabilitas arti luas. Apabila antar perlakuan berbeda nyata, maka dilanjutkan dengan uji beda 
nyata terkecil (BNT) pada taraf nyata $5 \%$.

Nilai BNT diperoleh dengan rumus:

BNT $\alpha=\mathrm{t}_{(1 / 2 \alpha)}(\mathrm{dbe}) \times \sqrt{\frac{2 K T G}{r}}$ dengan dbe merupakan derajat bebas galat; $\mathrm{t} 1 / 2 \alpha$, nilai distribusi pada $t$ tabel $\left(\mathrm{t}_{0.025}\right)$; KTG, kuadrat tengah galat dan $\mathrm{r}$ adalah jumlah blok.

Nilai heritabilitas arti luas dihitung dengan rumus (Ujianto et al. (2020):

$\mathrm{H}^{2}=\left(\sigma_{\mathrm{G}}^{2} / \sigma_{\mathrm{P}}^{2}\right) \times 100 \%$ dengan $\mathrm{H}^{2}$, heritabilitas arti luas $(\%) ; \sigma_{\mathrm{G}}^{2}$, ragam genetik; $\sigma^{2} \mathrm{P}$, ragam fenotipe. Ragam genetik $\left(\sigma^{2}\right)=(\mathrm{KTP}-\mathrm{KTG}) / \mathrm{r}$ dan $\sigma_{\mathrm{P}}^{2}=\sigma^{2}{ }_{\mathrm{G}}+\mathrm{KTG}$. Kriteria nilai heritabilitas ati luas dibuat dalam tiga katagori mengikuti kriteria yang dikemukakan oleh Syukur et al. (2012), yaitu yaitu, tergolong tinggi, $>50.00 \%$; sedang, $20.00-50.00 \%$ dan tergolong rendah apabila $\leq 20.00 \%$.

Koefisien keragaman genetik (KKG) setiap sifat, dapat dihitung dengan rumus (Ujianto, et al., 2020), sebagai berikut:

$\mathrm{KKG}=\frac{\sqrt{\sigma^{2} \mathrm{G}}}{\bar{x}} x 100 \% \quad$ dengan $\mathrm{KKG}$ merupakan koefisien keragaman genetik (\%) dan $\bar{x}$ adalah rata-rata umum. Selanjutnya nilai KKG dibuat dalam 3 kriteria mengikuti seperti dikemukakan oleh Istiningrum dan Damanhuri (2016), yaitu rendah $(<5 \%)$; sedang $(5-14.5$ $\%)$; dan tinggi (> $14.5 \%)$.

\section{HASIL DAN PEMBAHASAN}

Tabel 1. Rata-rata sudut daun, umur panen dan daya hasil galur-galur F2 dan tetuanya

\begin{tabular}{|c|c|c|c|c|c|c|c|c|c|c|c|c|c|c|c|}
\hline Genotipe & $\begin{array}{c}\text { Sudut } \\
\text { daun }\left({ }^{0}\right)\end{array}$ & 1 & 2 & 3 & 4 & $\begin{array}{c}\text { Umur } \\
\text { panen } \\
\text { (hari) }\end{array}$ & 1 & 2 & 3 & 4 & $\begin{array}{c}\text { Daya } \\
\text { hasil } \\
\text { (kg/plot) }\end{array}$ & 1 & 2 & 3 & 4 \\
\hline F2 P8IS x NK7328 (R6) & 37.22 & $\mathrm{a}$ & & & $\mathrm{a}$ & 99.00 & $\mathrm{~b}$ & & & $\mathrm{~b}$ & 4.958 & $\mathrm{a}$ & & & $\mathrm{a}$ \\
\hline F2 P8IS x NK7328 (8) & 34.18 & $\mathrm{a}$ & & & $\mathrm{b}$ & 99.00 & $\mathrm{~b}$ & & & $\mathrm{~b}$ & 8.094 & $\mathrm{~b}$ & & & $\mathrm{~b}$ \\
\hline F2 P8IS x NK7328 (R9) & 29.00 & a & & & $\mathrm{b}$ & 85.33 & $\mathrm{~b}$ & & & $\mathrm{~b}$ & 4.108 & $\mathrm{a}$ & & & $\mathrm{a}$ \\
\hline F2 P8IS x NK7328 (R11) & 30.31 & $\mathrm{a}$ & & & $\mathrm{b}$ & 82.00 & $\mathrm{~b}$ & & & $\mathrm{~b}$ & 5.249 & $\mathrm{a}$ & & & $\mathrm{a}$ \\
\hline F2 P8IS x NK7328 (14) & 39.17 & a & & & $\mathrm{a}$ & 82.00 & $\mathrm{~b}$ & & & $\mathrm{~b}$ & 3.671 & $\mathrm{~b}$ & & & $\mathrm{~b}$ \\
\hline F2 P8IS x NK7328 (R14) & 34.58 & $\mathrm{a}$ & & & $\mathrm{b}$ & 85.67 & $\mathrm{~b}$ & & & $\mathrm{~b}$ & 5.672 & $\mathrm{a}$ & & & $\mathrm{a}$ \\
\hline F2 P8IS x T1NK7328 (13) & 30.77 & & $\mathrm{a}$ & & $\mathrm{b}$ & 91.00 & & $\mathrm{a}$ & & $\mathrm{b}$ & 5.297 & & $\mathrm{a}$ & & $\mathrm{a}$ \\
\hline F2 P8IS x T1NK7328 (R16) & 30.68 & & $\mathrm{a}$ & & $\mathrm{b}$ & 79.00 & & $b$ & & $a$ & 4.886 & & $\mathrm{a}$ & & $\mathrm{a}$ \\
\hline F2 P8IS x T1NK7328 (R18) & 34.02 & & $\mathbf{a}$ & & b & 80.00 & & b & & $\mathbf{a}$ & 4.041 & & $\mathrm{a}$ & & $\mathrm{a}$ \\
\hline F2 P8IS x T1NK7328 (19) & 32.75 & & $\mathrm{a}$ & & $\mathrm{b}$ & 83.33 & & $\mathrm{~b}$ & & $\mathrm{~b}$ & 5.378 & & $\mathrm{a}$ & & $\mathrm{a}$ \\
\hline F2 P8IS x NK212 (R1) & 32.17 & & & $\mathrm{a}$ & $\mathrm{b}$ & 99.00 & & & $\mathrm{a}$ & $\mathrm{b}$ & 6.911 & & & $\mathrm{a}$ & $\mathrm{b}$ \\
\hline F2 P8IS x NK212 (2) & 38.33 & & & $\mathrm{~b}$ & $\mathrm{a}$ & 82.67 & & & $\mathrm{~b}$ & $\mathrm{~b}$ & 3.284 & & & $\mathrm{~b}$ & $\mathrm{a}$ \\
\hline F2 P8IS x NK212 (R3) & 35.00 & & & $\mathrm{a}$ & $\mathrm{b}$ & 87.33 & & & $\mathrm{~b}$ & $\mathrm{~b}$ & 5.227 & & & $\mathrm{a}$ & $\mathrm{a}$ \\
\hline F2 P8IS x NK212 (R4) & 31.11 & & & $\mathrm{a}$ & $\mathrm{b}$ & 79.00 & & & $\mathrm{~b}$ & $\mathrm{a}$ & 7.197 & & & $\mathrm{a}$ & $\mathrm{b}$ \\
\hline F2 P8IS x NK212 (5) & 40.94 & & & $\mathrm{~b}$ & $\mathrm{a}$ & 93.33 & & & $\mathrm{~b}$ & $\mathrm{~b}$ & 5.194 & & & $\mathrm{~b}$ & $\mathrm{a}$ \\
\hline F2 P8IS x NK212 (R5) & 32.25 & & & $\mathrm{a}$ & $\mathrm{b}$ & 83.33 & & & $\mathrm{~b}$ & $\mathrm{~b}$ & 5.335 & & & & $\mathrm{a}$ \\
\hline Tetua NK7328 & 32.73 & $\mathrm{a}$ & & & & 92.00 & $\mathrm{a}$ & & & & 5.162 & $\mathrm{a}$ & & & \\
\hline Tetua T1NK7328 & 30.80 & & $\mathrm{a}$ & & & 92.00 & & $\mathrm{a}$ & & & 4.782 & & $\mathrm{a}$ & & \\
\hline Tetua NK212 & 28.06 & & & $\mathrm{a}$ & & 100.33 & & & $\mathrm{a}$ & & 6.435 & & & $\mathrm{a}$ & \\
\hline Tetua Sinta Unram & 43.63 & & & & $\mathrm{a}$ & 78.33 & & & & $\mathrm{a}$ & 5.171 & & & & $\mathrm{a}$ \\
\hline $\mathrm{BNT}_{0,05}$ & 8.27 & & & & & 3.57 & & & & & 1.24 & & & & \\
\hline
\end{tabular}

Keterangan: Angka-angka pada kolom sama diikuti huruf sama tidak berbeda nyata dengan 1) NK7328; 2) T1NK7328; 3) NK212 dan 4) Sinta Unram didasarkan atas uji BNT pada taraf nyata 5 persen 
Pada Tabel 1 terlihat, bahwa sudut daun galur-galur F2 sama dengan sudut daun tetua hibrida dan turunan hibrida; kecuali galur F2 P8IS x NK212 (2), F2 P8IS x NK212 (5) dan F2 P8IS x NK7328 (R6). Ketiga galur tersebut memiliki sudut daun sama dengan Sinta Unram Umur panen yang tergolong super genjah dan sama dengan umur panen Sinta Unram diperoleh pada galur F2 P8IS x T1NK7328 (R16), F2 P8IS x T1NK7328 (R18) dan galur F2 P8IS x NK212 (R4). Galur-galur lain memiliki umur panen lebih dalam dibanding Sinta Unram. Khusus untuk galur F2 P8IS x NK7328 (R6) dan F2 P8IS x NK7328 (8) memiliki umur panen lebih dalam dibanding tetua hibridanya, yakni 99 hari; sedangkan umur panen tetua hibridanya (NK7328) 92 hari. Galur F2 P8IS x NK7328 (8) memiliki daya hasil lebih tinggi dibanding kedua tetua; sedangkan galur F2 P8IS x NK7328 (14), daya hasilnya lebih rendah dibanding kedua tetua. Galur F2 P8IS x NK212 (2) daya hasil sama dengan Sinta Unram, namun lebih rendah dibanding tetua hibrida; sedangkan galur F2 P8IS x NK212 (R1) dan F2 P8IS x NK212 (R4), daya hasil lebh tinggi dibanding Sinta Unram namun sama dengan tetua hibridanya (NK212).

Sifat kuantitatif merupakan karakter yang dikendalikan oleh banyak gen dan besar dipengaruhi oleh faktor lingkungan (Ishaq et al., 2015). Pada galur F2 terjadi segregasi, sehingga akan terjadi keragaman genetik untuk sifat kuantitatif tersebut. Sifat tetua yang hilang pada F1 ini, disebabkan karena tertutupnyan gen resesif oleh gen dominan dan pada F2 gen resesif yang membentuk sifat tertentu akan mulai menampakkan diri pada galur ini (Nugroho et al., 2014)..

Hibridisasi yang dilakukan bertujuan untuk memasukkan sifat sudut daun yang kecil dengan umur panen tetap super genjah dan hasil sama atau lebih tinggi dibanding P8IS. Hibridisasi dilakukan dengan menggunakan hibrida/turunan hibrida sebagai tetua jantan dan P8IS sebagai tetua betina. Resiprok (R) menggunakan P8IS (Sinta Unram) sebagai tetua jantan (Sudika dan Anugrahwati, 2020). Pada Tabel 1 terlihat, bahwa seluruh galur F2 memiliki sudut daun berkisar antara 29,00-40,94 . Balitbangtan (2004) mengemukakan, bahwa kriteria sudut daun tanaman jagung, yaitu amat kecil $\leq 5^{0}$; kecil $\pm 25^{\circ}$; sedang $\pm 50^{\circ}$; besar $\pm 75^{0}$ dan amat besar $\geq 90^{\circ}$. Pengelompokan tersebut sangat menyulitkan menggolongkan hasil penelitian yang telah diperoleh, sehingga atas dasar kriteria tersebut, dibuat kisarannya amat kecil: $<20^{\circ}$; kecil: $20-40^{\circ}$; Sedang: $>40-60^{\circ}$; Besar: $>60-80^{\circ}$ dan amat besar : $>80^{\circ}$. Atas dasar hal tersebut, sudut daun seluruh galur F2 berada pada kategori kecil, kecuali galur F2 P8IS x NK212 (5) (G15) tergolong sedang, yakni 40.39 ${ }^{\circ}$. Tetua P8IS memiliki sudut daun sebesar $43.63^{\circ}$ dan tegolong sedang. Sudut daun yang kecil sangat memungkinkan tanaman tersebut ditanam lebih rapat, sehingga hasil meningkat (Jaya et al., 2019).

Umur panen galur F2 hasil persilangan diharapkan tetap super genjah atau berubah menjadi genjah. Galur F2 P8IS x T1NK7328 (R16) (G8), F2 P8IS x T1NK7328 (R18) (G9) dan galur F2 P8IS x NK212 (R4) memiliki umur panen super genjah sama seperti umur panen P8IS dan enam galur F2 memiliki umur tergolong genjah. Galur F2 P8IS x T1NK7328 (R16), F2 P8IS x T1NK7328 (R18) (G9) dan F2 P8IS x NK212 (R4) merupakan hasil persilangan resiprok; berarti tetua jantannya adalah P8IS. Menurut Sudika (2015), bahwa umur panen super genjah dapat diturunkan melalui hibridisasi apabila tanaman tersebut digunakan sebagai tetua jantan. Dua galur F2 tersebut berasal dari resiprok turunan pertama hibrida NK7328 dan satu 
galur F2 berasal dari persilangan resiprok dengan NK212. Hal ini dapat dipahami, bahwa turunan pertama hibrida memiliki genotipe yang tidak sama antar individu akibat telah terjadi segregasi. Hal tersebut sangat memungkinkan untuk memperoleh berbagai macam galur apabila disilangkan dengan komposit (P8IS); berarti peluang memperoleh galur super genjah lebih besar dibanding persilangan hibrida dengan P8IS. Katagori umur panen tersebut, sesuai dengan penggolongan yang dikemukakan oleh Azrai (2013) bahwa umur panen jagung digolongkan menjadi 5 yaitu jagung berumur ultra genjah (< 70 hari); super genjah (70- 80 hari); genjah (81-90 hari); sedang ( 91 - 110 hari) dan berumur dalam ( $>110$ hari).

Ketiga galur F2 yang memiliki umur super genjah, dua galur memiliki daya hasil sama dengan Sinta Unram dan satu galur lebih tinggi dibanding Sinta Unram. Hal ini menunjukkan, bahwa ketiga galur tersebut dapat digunakan sebagai populasi dasar. Terjadi kecendrungan peningkatan daya hasil (bobot biji kering pipil per plot) seiring dengan bertambahnya umur panen dengan nilai koefisien korelasi bersifat positif nyata sebesar 0,42 (Tabel 4). Hal ini kemungkinan disebabkan oleh terjadinya massa pengisian biji yang lebih lama; namun potensi genetik setiap galur tetap menentukan hasil. Kusnarta dan Sudika (2018) menjelaskan bahwa semakin lama umur panen (dalam rentan waktu tertentu), maka akan terjadi pengisian biji lebih banyak sehingga hasil lebih tinggi. Galur F2 P8IS x T1NK7328 (R16), F2 P8IS x T1NK7328 (R18) (G9) dan galur F2 P8IS x NK212 (R4) memiliki hasil sama dengan tetua hibrida/turunan pertama hibrida dan tetua Sinta Unram. Galur G2 (F2 P8IS x NK7328 (8), memiliki daya hasil lebih tinggi dibanding kedua tetua, namun umur panen tergolong sedang, yakni 99 hari.

Selain umur panen, sifat-sifat kuantitatif lainnya yang memiliki koefisien korelasi positif nyata dengan hasil, yaitu jumlah daun per tanaman, brangkasan segar per tanaman dan seluruh komponen hasil yang diamati (Tabel 4). Bobot brangkasan segar G2 lebih tinggi dibanding tetua hibrida (Tabel 2), sehingga hasilnya lebih tinggi. Hal ini sesuai dengan laporan Yulisma (2011) tentang adanya korelasi positif antara variabel pertumbuhan vegetatif (tinggi tanaman, jumlah daun dan bobot brangkasan segar) terhadap daya hasil tanaman jagung.

Variabel pembungaan, meliputi umur keluar malai, umur keluar rambut tongkol dan ASI tidak berpengaruh terhadap daya hasil terlihat dari nilai koefisien korelasinya tidak nyata dan tergolong sangat lemah. Nilai koefisien korelasi daya hasil dengan umur keluar malai, umur keluar rambut tongkol dan ASI berturut-turut sebesar 0.19; 0,19 dan -0.04 (Tabel 4). Hal sama diperoleh oleh Sudika (2015), bahwa umur keluar malai, umur keluar rambut tongkol dan ASI memiliki korelasi tidak nyata dengan hasil galur F1 jagung hasil persilangan PHRKL vs tiga hibrida.

Komponen hasil juga mendukung bahwa G2 hasilnya lebih tinggi dibanding kedua tetua. Galur G2 memiliki bobot tongkol kering panen lebih tinggi dibanding Sinta Unram dan cenderung lebih tinggi dibanding tetua hibrida. Bobot 1.000 butir biji G2 lebih tinggi dibanding kedua tetua (Tabel 3). Bobot 1.000 butir biji menggambarkan kualitas biji; yaitu ukuran dan kebernasan. Hal ini berarti biji G2 lebih bernas dan ukurannya lebih besar dibanding kedua tetua dan beberapa galur F 2 lain. Galur G8 dan galur G9 memiliki panjang tongkol dan bobot tongkol kering panen yang sama dengan kedua tetua, sehingga hasil sama dengan kedua tetua. Keterkaitan antara daya hasil dengan komponen hasil, seluruhnya positif nyata dengan katagori sedang, kecuali bobot tongkol kering panen yang memiliki katagori kuat. Tongkol yang 
semakin berat menunjukkan jumlah biji yang semakin banyak dan adanya bobot 1.000 butir biji yang semakin tinggi menyebabkan daya hasil yang semakin tinggi. Korelasi positif nyata antara daya hasil dengan bobot tongkol kering panen, diperoleh pula oleh Abdalla, et al. (2010)

Tabel 2. Rata-rata untuk variabel pertumbuhan galur-galur F2 dan tetuanya

\begin{tabular}{|c|c|c|c|c|c|c|c|c|c|c|c|}
\hline No. & Genotipe & TT & 1) & 2) & 3) & 4) & JD & 1) & 2) & 3) & 4) \\
\hline 1 & F2 P8IS x NK7328 (R6) & 138.47 & $\mathrm{~b}$ & & & $\mathrm{~b}$ & 13.44 & $\mathrm{~b}$ & & & $\mathrm{a}$ \\
\hline 2 & F2 P8IS x NK7328 (8) & 143.48 & $\mathrm{~b}$ & & & $\mathrm{~b}$ & 15.51 & $\mathrm{a}$ & & & $\mathrm{b}$ \\
\hline 3 & F2 P8IS x NK7328 (R9) & 149.22 & $\mathrm{a}$ & & & $\mathrm{b}$ & 12.00 & $\mathrm{~b}$ & & & $\mathrm{~b}$ \\
\hline 4 & F2 P8IS x NK7328 (R11) & 148.58 & $\mathrm{a}$ & & & $\mathrm{b}$ & 13.16 & $\mathrm{~b}$ & & & $\mathrm{a}$ \\
\hline 5 & F2 P8IS x NK7328 (14) & 139.36 & $\mathrm{~b}$ & & & $\mathrm{~b}$ & 11.92 & $\mathrm{~b}$ & & & $\mathrm{~b}$ \\
\hline 6 & F2 P8IS x NK7328 (R14) & 144.00 & $\mathrm{~b}$ & & & $\mathrm{~b}$ & 13.08 & $\mathrm{~b}$ & & & $\mathrm{a}$ \\
\hline 7 & F2 P8IS x T1NK7328 (13) & 162.48 & & $\mathrm{a}$ & & $\mathrm{a}$ & 13.75 & & $\mathrm{~b}$ & & $\mathrm{a}$ \\
\hline 8 & F2 P8IS x T1NK7328 (R16) & 151.28 & & $\mathrm{a}$ & & $\mathrm{b}$ & 12.67 & & $\mathrm{~b}$ & & $\mathrm{a}$ \\
\hline 9 & F2 P8IS x T1NK7328 (R18) & 149.62 & & $\mathrm{a}$ & & $\mathrm{b}$ & 12.52 & & $\mathrm{~b}$ & & $\mathrm{a}$ \\
\hline 10 & F2 P8IS x T1NK7328 (19) & 151.31 & & $\mathrm{a}$ & & $\mathrm{b}$ & 13.92 & & $\mathrm{~b}$ & & $\mathrm{a}$ \\
\hline 11 & F2 P8IS x NK212 (R1) & 149.91 & & & $\mathrm{a}$ & $\mathrm{b}$ & 14.61 & & & $\mathrm{a}$ & $\mathrm{a}$ \\
\hline 12 & F2 P8IS x NK212 (2) & 140.13 & & & $\mathrm{~b}$ & $\mathrm{~b}$ & 10.28 & & & $\mathrm{~b}$ & $\mathrm{~b}$ \\
\hline 13 & F2 P8IS x NK212 (R3) & 149.17 & & & $\mathrm{a}$ & $\mathrm{b}$ & 13.50 & & & $\mathrm{a}$ & $\mathrm{a}$ \\
\hline 14 & F2 P8IS x NK212(R4) & 162.99 & & & $\mathrm{a}$ & $\mathrm{a}$ & 12.89 & & & $\mathrm{~b}$ & $\mathrm{a}$ \\
\hline 15 & F2 P8IS x NK212 (5) & 153.89 & & & $\mathrm{a}$ & $\mathrm{a}$ & 15.28 & & & $\mathrm{a}$ & $\mathrm{a}$ \\
\hline 16 & F2 P8IS x NK212 (R5) & 149.18 & & & $\mathrm{a}$ & $\mathrm{b}$ & 13.50 & & & $\mathrm{a}$ & $\mathrm{a}$ \\
\hline 17 & Tetua NK7328 & 169.28 & $\mathrm{a}$ & & & & 16.47 & $\mathrm{a}$ & & & \\
\hline 18 & Tetua T1NK7328 & 165.61 & & $\mathrm{a}$ & & & 15.85 & & $\mathrm{a}$ & & \\
\hline 19 & Tetua NK212 & 168.39 & & & $\mathrm{a}$ & & 14.89 & & & $\mathrm{a}$ & \\
\hline 20 & Tetua Sinta Unram & 175.54 & & & & $\mathrm{a}$ & 13.94 & & & & $\mathrm{a}$ \\
\hline & $\mathrm{BNT}_{0,05}$ & 24.10 & & & & & 1.55 & & & & \\
\hline
\end{tabular}

Lanjutan Tabel 2.

\begin{tabular}{|c|c|c|c|c|c|c|c|c|c|c|c|}
\hline No. & Genotipe & JDS & 1) & 2) & 3) & 4) & BBS & 1) & 2) & 3) & 4) \\
\hline 1 & F2 P8IS x NK7328 (R6) & 10.83 & $\mathrm{a}$ & & & $\mathrm{a}$ & 482.60 & $\mathrm{a}$ & & & \\
\hline 2 & F2 P8IS x NK7328 (8) & 9.47 & a & & & a & 564.90 & $\mathrm{~b}$ & & & a \\
\hline 3 & F2 P8IS x NK7328 (R9) & 7.67 & a & & & a & 299.63 & $\mathrm{a}$ & & & $\mathrm{b}$ \\
\hline 4 & F2 P8IS x NK7328 (R11) & 7.47 & $\mathrm{a}$ & & & $\mathrm{a}$ & 360.98 & a & & & $\mathrm{a}$ \\
\hline 5 & F2 P8IS x NK7328 (14) & 6.86 & $\mathrm{~b}$ & & & $\mathrm{~b}$ & 299.41 & a & & & $\mathrm{b}$ \\
\hline 6 & F2 P8IS x NK7328 (R14) & 7.87 & $\mathrm{a}$ & & & $\mathrm{a}$ & 364.04 & a & & & $\mathrm{a}$ \\
\hline 7 & F2 P8IS x T1NK7328 (13) & 6.71 & & $\mathrm{~b}$ & & $\mathrm{~b}$ & 344.17 & & a & & $\mathrm{b}$ \\
\hline 8 & F2 P8IS x T1NK7328 (R16) & 7.63 & & $\mathrm{~b}$ & & $\mathrm{a}$ & 453.28 & & a & & $\mathrm{a}$ \\
\hline 9 & F2 P8IS x T1NK7328 (R18) & 6.52 & & $\mathrm{~b}$ & & $\mathrm{~b}$ & 340.14 & & $\mathrm{a}$ & & $\mathrm{b}$ \\
\hline 10 & F2 P8IS x T1NK7328 (19) & 7.13 & & $\mathrm{~b}$ & & $\mathrm{a}$ & 400.71 & & a & & $\mathrm{a}$ \\
\hline 11 & F2 P8IS x NK212 (R1) & 9.75 & & & $\mathrm{a}$ & $\mathrm{a}$ & 425.33 & & & a & $\mathrm{a}$ \\
\hline 12 & F2 P8IS x NK212 (2) & 6.38 & & & $\mathrm{a}$ & $\mathrm{b}$ & 362.16 & & & $\mathrm{a}$ & a \\
\hline 13 & F2 P8IS x NK212 (R3) & 6.38 & & & $\mathrm{a}$ & $\mathrm{b}$ & 429.19 & & & $\mathrm{a}$ & a \\
\hline 14 & F2 P8IS x NK212 (R4) & 8.66 & & & $\mathrm{a}$ & $\mathrm{a}$ & 474.01 & & & $\mathrm{a}$ & $\mathrm{a}$ \\
\hline 15 & F2 P8IS x NK212 (5) & 7.44 & & & $\mathrm{a}$ & $\mathrm{a}$ & 523.00 & & & $\mathrm{a}$ & $\mathrm{a}$ \\
\hline 16 & F2 P8IS x NK212 (R5) & 6.99 & & & $\mathrm{a}$ & $\mathrm{b}$ & 420.46 & & & $\mathrm{a}$ & $\mathrm{a}$ \\
\hline 17 & Tetua NK7328 & 9.75 & $\mathrm{a}$ & & & & 419.29 & $\mathrm{a}$ & & & \\
\hline 18 & Tetua T1NK7328 & 9.71 & & $\mathrm{a}$ & & & 432.47 & & $\mathrm{a}$ & & \\
\hline 19 & Tetua NK212 & 8.14 & & & $\mathrm{a}$ & & 449.00 & & & $\mathrm{a}$ & \\
\hline \multirow[t]{2}{*}{20} & Tetua Sinta Unram & 9.38 & & & & $\mathrm{a}$ & 471.65 & & & & $\mathrm{a}$ \\
\hline & $\mathrm{BNT}_{0,05}$ & 2.01 & & & & & 126.91 & & & & \\
\hline
\end{tabular}


Lanjutan Tabel 2.

\begin{tabular}{llcccrr}
\hline No. & Genotipe & DB & 1) & 2) & 3) & 4) \\
\hline 1 & F2 P8IS x NK7328 (R6) & 2.94 & $\mathrm{~b}$ & & & $\mathrm{a}$ \\
2 & F2 P8IS x NK7328 (8) & 3.30 & $\mathrm{~b}$ & & & $\mathrm{~b}$ \\
3 & F2 P8IS x NK7328 (R9) & 2.30 & $\mathrm{a}$ & & & $\mathrm{a}$ \\
4 & F2 P8IS x NK7328 (R11) & 2.52 & $\mathrm{a}$ & & & $\mathrm{a}$ \\
5 & F2 P8IS x NK7328 (14) & 2.59 & $\mathrm{a}$ & & & $\mathrm{a}$ \\
6 & F2 P8IS x NK7328 (R14) & 2.63 & $\mathrm{a}$ & & & $\mathrm{a}$ \\
7 & F2 P8IS x T1NK7328 (13) & 2.64 & & $\mathrm{a}$ & & $\mathrm{a}$ \\
8 & F2 P8IS x T1NK7328 (R16) & 2.32 & & $\mathrm{a}$ & & $\mathrm{a}$ \\
9 & F2 P8IS x T1NK7328 (R18) & 2.73 & & $\mathrm{a}$ & & $\mathrm{a}$ \\
10 & F2 P8IS x T1NK7328(19) & 2.65 & & $\mathrm{a}$ & & $\mathrm{a}$ \\
11 & F2 P8IS x NK212(R1) & 2.87 & & & $\mathrm{a}$ & $\mathrm{a}$ \\
12 & F2 P8IS x NK212(2) & 2.67 & & & $\mathrm{a}$ & $\mathrm{a}$ \\
13 & F2 P8IS x NK212(R3) & 3.17 & & & $\mathrm{a}$ & $\mathrm{b}$ \\
14 & F2 P8IS x NK212(R4) & 2.58 & & & $\mathrm{a}$ & $\mathrm{a}$ \\
15 & F2 P8IS x NK212(5) & 3.36 & & & $\mathrm{a}$ & $\mathrm{b}$ \\
16 & F2 P8IS x NK212(R5) & 3.01 & & & $\mathrm{a}$ & $\mathrm{b}$ \\
17 & Tetua NK7328 & 2.21 & $\mathrm{a}$ & & & \\
18 & Tetua T1NK7328 & 2.60 & & $\mathrm{a}$ & & \\
19 & Tetua NK212 & 2.93 & & & $\mathrm{a}$ & \\
20 & Tetua Sinta Unram & 2.41 & & & & $\mathrm{a}$ \\
& $\quad$ BNT 0.05 & 0.59 & & & \\
\hline
\end{tabular}

Keterangan: TT, tinggi tanaman (cm); JD, jumlah daun per tanaman (helai) dan DB, diameter batang (cm); JDS, jumlah daun segar saat panen per tanaman (helai); BBS, bobot brangkasan segar per tanaman (g); angka-angka pada kolom sama diikuti huruf sama tidak berbeda nyata dengan 1) NK7328; 2) T1NK7328; 3) NK212 dan 4) Sinta Unram didasarkan atas uji BNT pada taraf nyata 5 persen.

Pada Tabel 2 dapat dilihat, bahwa galur F2 F2 P8IS x T1NK7328 (13), F2 P8IS x NK212 (R4) dan galur F2 P8IS x NK212 (5) memiliki tinggi tanaman sama dengan kedua tetua; sedangkan galur F2 lainnya lebih pendek dibanding dengan Sinta Unram. Galur F2 P8IS x NK7328 (8) memiliki jumlah daun lebih banyak dibanding Sinta Unram; namun sama dengan tetua hibridanya (NK7328). Diameter batang galur F2 yang sama dengan diameter batang Sinta Unram diperoleh sebanyak 12 galur; sedangkan yang lebih besar sebanyak 4 galur, yaitu F2 P8IS x NK7328 (8), F2 P8IS x NK212 (R3), F2 P8IS x NK212 (5) dan galur F2 P8IS x NK212 (R5). Diantara keempat galur F2 tersebut, hanya galur F2 P8IS x NK7328 (8); yang memiliki diameter batang lebih besar dibanding tetua hibridanya. Galur F2 hasil persilangan NK7328 vs Sinta Unram memiliki jumlah daun segar saat panen per tanaman sama dengan kedua tetua, kecuali galur F2 P8IS x NK7328 (14), lebih sedikit dibanding kedua tetua. Seluruh galur hasil persilangan turunan pertama NK7328 vs Sinta Unram, memiliki jumlah daun segar saat panen lebih sedikit dibanding tetua turunan hibridanya. Terdapat tiga galur F2 hasil persilangan NK212 vs Sinta Unram, memiliki jumlah daun sama dengan tetua Sinta Unram dan seluruh galur F2 sama dengan tetua hibrida. Bobot brangkasan segar per tanaman merupakan penciri stay-green. Pada Lanjutan Tabel 2 terlihat, bahwa bobot brangkasan segar per tanaman galur F2 hasil persilangan turunan NK7328 sama dengan tetua turunan pertama hibrida dan Sinta Unram, kecuali galur F2 P8IS x T1NK7328 (13) dan F2 P8IS x T1NK7328 (R18) lebih rendah dibanding Sinta Unram. Seluruh galur F2 hasil persilangan dengan NK212, memiliki bobot brangkasan segar per tanaman sama dengan kedua tetua. 
Tabel 3. Rata-rata untuk variabel komponen hasil galur-galur F2 dan tetuanya

\begin{tabular}{|c|c|c|c|c|c|c|c|c|c|c|c|}
\hline No. & Genotipe & BTKP & 1) & 2) & 3) & 4) & PT & 1) & 2) & 3) & 4) \\
\hline 1 & F2 P8IS x NK7328 (R6) & 162.02 & $\mathrm{a}$ & & & $\mathrm{a}$ & 14.47 & $\mathrm{a}$ & & & $\mathrm{a}$ \\
\hline 2 & F2 P8IS x NK7328 (8) & 256.94 & $\mathrm{a}$ & & & $\mathrm{b}$ & 15.75 & $\mathrm{a}$ & & & $\mathrm{a}$ \\
\hline 3 & F2 P8IS x NK7328 (R9) & 153.04 & $\mathrm{~b}$ & & & $\mathrm{a}$ & 14.07 & $\mathrm{~b}$ & & & $\mathrm{a}$ \\
\hline 4 & F2 P8IS x NK7328 (R11) & 180.13 & $\mathrm{a}$ & & & $\mathrm{a}$ & 16.52 & $\mathrm{a}$ & & & $\mathrm{a}$ \\
\hline 5 & F2 P8IS x NK7328 (14) & 150.18 & $\mathrm{~b}$ & & & $\mathrm{~b}$ & 13.72 & $\mathrm{~b}$ & & & $\mathrm{a}$ \\
\hline 6 & F2 P8IS x NK7328 (R14) & 210.27 & $\mathrm{a}$ & & & $\mathrm{a}$ & 15.46 & $\mathrm{a}$ & & & $\mathrm{a}$ \\
\hline 7 & F2 P8IS x T1NK7328 (13) & 201.99 & & $\mathrm{a}$ & & $\mathrm{a}$ & 14.62 & & $\mathrm{a}$ & & $\mathrm{a}$ \\
\hline 8 & F2 P8IS x T1NK7328 (R16) & 203.86 & & $\mathrm{a}$ & & $\mathrm{a}$ & 15.71 & & $\mathrm{a}$ & & $\mathrm{a}$ \\
\hline 9 & F2 P8IS x T1NK7328 (R18) & 161.99 & & $\mathrm{a}$ & & $\mathrm{a}$ & 16.29 & & $\mathrm{a}$ & & $\mathrm{a}$ \\
\hline 10 & F2 P8IS x T1NK7328 (19) & 201.90 & & $\mathrm{a}$ & & $\mathrm{a}$ & 16.73 & & $\mathrm{a}$ & & $\mathrm{a}$ \\
\hline 11 & F2 P8IS x NK212 (R1) & 182.47 & & & $\mathrm{~b}$ & $\mathrm{a}$ & 14.32 & & & $\mathrm{~b}$ & $\mathrm{a}$ \\
\hline 12 & F2 P8IS x NK212 (2) & 165.34 & & & $\mathrm{~b}$ & $\mathrm{a}$ & 14.97 & & & $\mathrm{a}$ & $\mathrm{a}$ \\
\hline 13 & F2 P8IS x NK212 (R3) & 201.05 & & & $\mathrm{a}$ & $\mathrm{a}$ & 16.33 & & & $\mathrm{a}$ & $\mathrm{a}$ \\
\hline 14 & F2 P8IS x NK212(R4) & 221.64 & & & $\mathrm{a}$ & $\mathrm{a}$ & 15.41 & & & $\mathrm{a}$ & $\mathrm{a}$ \\
\hline 15 & F2 P8IS x NK212 (5) & 210.56 & & & $\mathrm{a}$ & $\mathrm{a}$ & 16.00 & & & $\mathrm{a}$ & $\mathrm{a}$ \\
\hline 16 & F2 P8IS x NK212 (R5) & 192.32 & & & $\mathrm{~b}$ & $\mathrm{a}$ & 14.04 & & & $\mathrm{~b}$ & $\mathrm{a}$ \\
\hline 17 & Tetua NK7328 & 211.85 & $\mathrm{a}$ & & & & 16.38 & $\mathrm{a}$ & & & \\
\hline 18 & Tetua T1NK7328 & 194.29 & & $\mathrm{a}$ & & & 14.78 & & $\mathrm{a}$ & & \\
\hline 19 & Tetua NK212 & 244.94 & & & $\mathrm{a}$ & & 16.89 & & & $\mathrm{a}$ & \\
\hline \multirow[t]{2}{*}{20} & Tetua Sinta Unram & 203.80 & & & & $\mathrm{a}$ & 14.80 & & & & $\mathrm{a}$ \\
\hline & $\mathrm{BNT}_{0,05}$ & 52.50 & & & & & 2.03 & & & & \\
\hline
\end{tabular}

Lanjutan Tabel 3.

\begin{tabular}{|c|c|c|c|c|c|c|c|c|c|c|c|}
\hline No. & Genotipe & DT & 1) & 2) & 3) & 4) & BS & 1) & 2) & 3) & 4) \\
\hline 1 & F2 P8IS x NK7328 (R6) & 4.38 & $\mathrm{a}$ & & & $\mathrm{a}$ & 331.17 & $\mathrm{~b}$ & & & $\mathrm{~b}$ \\
\hline 2 & F2 P8IS x NK7328 (8) & 4.86 & $\mathrm{a}$ & & & $\mathrm{a}$ & 328.62 & $\mathrm{~b}$ & & & $\mathrm{~b}$ \\
\hline 3 & F2 P8IS x NK7328 (R9) & 4.50 & $\mathrm{a}$ & & & $\mathrm{a}$ & 182.94 & $\mathrm{~b}$ & & & $\mathrm{~b}$ \\
\hline 4 & F2 P8IS x NK7328 (R11) & 4.44 & $\mathrm{a}$ & & & $\mathrm{a}$ & 256.50 & $\mathrm{a}$ & & & $\mathrm{a}$ \\
\hline 5 & F2 P8IS x NK7328 (14) & 4.56 & $\mathrm{a}$ & & & $\mathrm{a}$ & 248.94 & $\mathrm{a}$ & & & $\mathrm{a}$ \\
\hline 6 & F2 P8IS x NK7328 (R14) & 4.76 & $\mathrm{a}$ & & & $\mathrm{a}$ & 277.44 & $\mathrm{~b}$ & & & $\mathrm{a}$ \\
\hline 7 & F2 P8IS x T1NK7328 (13) & 4.96 & & $\mathrm{a}$ & & $\mathrm{b}$ & 316.67 & & $\mathrm{~b}$ & & $\mathrm{~b}$ \\
\hline 8 & F2 P8IS x T1NK7328 (R16) & 4.23 & & $\mathrm{~b}$ & & $\mathrm{a}$ & 216.44 & & $\mathrm{~b}$ & & $\mathrm{~b}$ \\
\hline 9 & F2 P8IS x T1NK7328 (R18) & 4.21 & & $\mathrm{~b}$ & & $\mathrm{~b}$ & 256.39 & & a & & $\mathrm{a}$ \\
\hline 10 & F2 P8IS x T1NK7328 (19) & 4.64 & & $\mathrm{a}$ & & $\mathrm{a}$ & 258.94 & & a & & $\mathrm{a}$ \\
\hline 11 & F2 P8IS x NK212 (R1) & 4.45 & & & $\mathrm{~b}$ & $\mathrm{a}$ & 296.50 & & & $\mathrm{a}$ & $\mathrm{a}$ \\
\hline 12 & F2 P8IS x NK212 (2) & 4.22 & & & $\mathrm{~b}$ & $\mathrm{a}$ & 235.32 & & & $\mathrm{~b}$ & $\mathrm{~b}$ \\
\hline 13 & F2 P8IS x NK212 (R3) & 4.64 & & & $\mathrm{a}$ & $\mathrm{a}$ & 250.78 & & & $\mathrm{a}$ & $\mathrm{a}$ \\
\hline 14 & F2 P8IS x NK212 (R4) & 4.77 & & & $\mathrm{a}$ & $\mathrm{a}$ & 254.04 & & & $\mathrm{a}$ & $\mathrm{a}$ \\
\hline 15 & F2 P8IS x NK212 (5) & 4.82 & & & $\mathrm{a}$ & $\mathrm{a}$ & 278.33 & & & $\mathrm{a}$ & $\mathrm{a}$ \\
\hline 16 & F2 P8IS x NK212 (R5) & 4.77 & & & $\mathrm{a}$ & $\mathrm{a}$ & 253.27 & & & $\mathrm{a}$ & $\mathrm{a}$ \\
\hline 17 & Tetua NK7328 & 4.70 & $\mathrm{a}$ & & & & 238.43 & $\mathrm{a}$ & & & \\
\hline 18 & Tetua T1NK7328 & 4.69 & & $\mathrm{a}$ & & & 257.57 & & $\mathrm{a}$ & & \\
\hline 19 & Tetua NK212 & 4.84 & & & $\mathrm{a}$ & & 269.33 & & & $\mathrm{a}$ & \\
\hline 20 & Tetua Sinta Unram & 4.58 & & & & $\mathrm{a}$ & 270.46 & & & & $\mathrm{a}$ \\
\hline \multicolumn{2}{|c|}{$\mathrm{BNT}_{0,05}$} & 0.36 & & & & & 31.90 & & & & \\
\hline
\end{tabular}

Keterangan: BTKP, bobot tongkol kering panen per tanaman (g); PT, panjang tongkol (cm); DT, diameter tongkol (cm) dan BS, bobot 1.000 butir biji (g); angka-angka pada kolom sama diikuti huruf sama tidak berbeda nyata dengan 1) NK7328; 2) T1NK7328; 3) NK212 dan 4) Sinta Unram didasarkan atas uji BNT pada taraf nyata 5 persen 
Pada Tabel 3 terlihat, bobot tongkol kering panen per tanaman lebih tinggi dibandingkan dengan Sinta Unram diperoleh pada galur F2 P8IS x NK7328 (8) dan sama dengan tetua hibridanya. Satu galur F2 yang memiliki bobot tongkol lebih rendah dibandingkan dengan Sinta Unram dan tetua hibrida, yakni galur F2 P8IS x NK7328 (14). Seluruh galur F2 hasil persilangan turunan hibrida NK7328 vs Sinta Unram memiliki bobot tongkol kering panen sama dengan kedua tetua. Persilangan NK212 vs Sinta Unram, tiga galur bobot tongkol kering panen sama dengan kedua tetua; sedangkan tiga lainnya lebih rendah dibanding tetua hibridanya.

Panjang tongkol semua galur F2 sama dengan Sinta Unram; namun terdapat empat galur F2 lebih pendek dibanding tetua hibridanya, yaitu galur F2 P8IS x NK7328 (R9), F2 P8IS x NK7328 (14), F2 P8IS x NK212 (R1) dan galur F2 P8IS x NK212 (R5). Diameter tongkol seluruh F2 hasil persilangan NK7328 vs Sinta Unram sama dengan kedua tetua. Galur F2 P8IS x T1NK7328 (13), diameter tongkolnya lebih besar dibanding hanya dengan Sinta Unram; sedangkan diameter tongkol galur F2 P8IS x T1NK7328 (R18) lebih kecil dibanding kedua tetua. Tiga galur F2 , yaitu F2 P8IS x NK7328 (R6), F2 P8IS x NK7328 (8) dan F2 P8IS x T1NK7328 (13) memiliki bobot 1.000 butir biji lebih tinggi dibanding kedua tetua. Galur F2 P8IS x T1NK7328 (R16) dan F2 P8IS x NK212 (2), bobot 1.000 butir biji lebih rendah dibanding kedua tetua.

Tabel 4. Nilai koefisien korelasi antar daya hasil dan bobot brangkasan segar (BBS) dengan sifat-sifat lain diamati

\begin{tabular}{|c|c|c|c|c|}
\hline Sifat yang diamati & $\begin{array}{l}\text { Daya } \\
\text { hasil }\end{array}$ & Kriteria & BBS & Kriteria \\
\hline Umur keluar malai & $0.19 \mathrm{~ns}$ & Sangat lemah & $0.14 \mathrm{~ns}$ & Sangat lemah \\
\hline Umur keluar rambut tongkol & $0.19 \mathrm{~ns}$ & Sangat lemah & $0.15 \mathrm{~ns}$ & Sangat lemah \\
\hline $\begin{array}{l}\text { Selisih umur keluar rambut tongkol } \\
\text { dengan keluar malai (ASI) }\end{array}$ & $-0.04 \mathrm{~ns}$ & Sangat lemah & $0.01 \mathrm{~ns}$ & Sangat lemah \\
\hline Umur panen & $0.42 \mathrm{~s}$ & Sedang & $0.31 \mathrm{~s}$ & Lemah \\
\hline Sudut daun & $-0.21 \mathrm{~ns}$ & Lemah & $0.29 \mathrm{~s}$ & Lemah \\
\hline Tinggi tanaman & $0.17 \mathrm{~ns}$ & Sangat lemah & $0.16 \mathrm{~ns}$ & Sangat lemah \\
\hline Jumlah daun per tanaman & $0.47 \mathrm{~s}$ & Sedang & $0.39 \mathrm{~s}$ & Lemah \\
\hline Diameter batang & $0.30 \mathrm{~s}$ & Lemah & $0.37 \mathrm{~s}$ & Lemah \\
\hline Jumlah da & $0.39 \mathrm{~s}$ & Lemah & $0.51 \mathrm{~s}$ & Sedang \\
\hline Bobot br & $0.46 \mathrm{~s}$ & Sedang & 1 & \\
\hline Bobot tongkol kering panen per tanaman & $0.74 \mathrm{~s}$ & Kuat & $0.56 \mathrm{~s}$ & Sedang \\
\hline Panjang tongkol & $0.44 \mathrm{~s}$ & Sedang & $0.32 \mathrm{~s}$ & Lemah \\
\hline Diameter tongkol & $0.52 \mathrm{~s}$ & Sedang & $0.37 \mathrm{~s}$ & Lemah \\
\hline Daya hasil (bobot & 1 & & $0.54 \mathrm{~s}$ & Sedang \\
\hline Bobot 1.000 butir biji & $0.49 \mathrm{~s}$ & Sedang & $0.32 \mathrm{~s}$ & Lemah \\
\hline
\end{tabular}

Pada Tabel 4 terlihat, bahwa umur keluar malai, umur keluar rambut tongkol, ASI, sudut daun dan tinggi tanaman memiliki korelasi tidak nyata dengan daya hasil dan tergolong sangat lemah. Umur panen, jumlah daun per tanaman, diameter batang dan jumah daun segar saat panen per tanaman korelasinya nyata dan tergolong lemah. Korelasi yang nyata dan tergolong sedang, diperoleh pada sifat bobot brangkasan segar per tanaman, panjang tongkol, 
diameter tongkol dan bobot 1.000 butir biji; sedangkan bobot tongkol kering panen per tanaman krelasinya tergolong kuat dengan daya hasil. Korelasi sangat lemah dengan bobot brangkasan segar diperoleh pada sifat umur keluar malai, umur keluar rambut tongkol, ASI dan tingg tanaman. Katagori lemah diperoleh pada sifat umur panen, sudut daun, jumlah daun per tanaman, diameter batang, panjang tongkol, diameter tongkol dan bobot 1.000 butir biji. Sifat jumlah daun segar saat panen per tanaman, bobot tongkol kering panen dan daya hasil memiliki korelasi tergolong sedang.

Pada Tabel 5 terlihat, bahwa nilai koefisien keragaman genetik tergolong tinggi diperoleh pada sifat selisih keluar rambut tongkol dengan umur keluar malai (ASI) dan daya hasil (bobot tongkol kering pipil per plot). Sifat sudut daun, tinggi tanaman dan panjang tongkol, koefisien keragaman genetik tergolong rendah dan yang tergolong sedang, yaitu umur keluar malai, umur keluar rambut tongkol, umur panen, jumah daun per tanaman, diameter batang, jumlah daun segar saat panen, bobot brangkasan segar, bobot tongkol kering panen dan bobot 1.000 butir biji, Koefisien keragaman genetik (KKG), digunakan untuk membandingkan keragaman genetik antar sifat dari galur-galur F2 yang diuji tanpa mengikut-sertakan tetua dalam analisisnya. Iqra (2019), juga memperoleh nilai koefisien keragaman genetik tergolong sedang untuk bobot tongkol kering panen. Menurut Syukur et al. (2012), bahwa sifat-sifat yang memiliki koefisien keragaman genetik rendah; berarti memiliki keragaman genetik sempit; sedang berarti keragaman genetiknya cukup dan nilai KKG tergolong tinggi menunjukkan keragaman genetik luas. Keragaman genetik yang sempit menunjukkan bahwa seleksi terhadap suatu karakter sudah tidak efektif lagi dilakukan sedangkan adanya keragaman genetik yang luas memudahkan pemilihan genotip-genotip unggul sesuai dengan karakter yang diinginkan. Adanya keragaman genetik luas menunjukkan bahwa apabila dilakukan seleksi terhadap sifat tersebut, maka akan memiliki kemajuan seleksi lebih besar dibanding sifat yang memiliki keragaman genetik cukup atau sempit (Basuki, 2005). Besarnya kemajuan seleksi selain ditentukan keragaman genetik, juga tergantung dari nilai heritabilitas.

Tabel 5. Nilai heritabilitas arti luas $\left(\mathrm{H}^{2}\right)$ dan nilai koefisien keragaman genetik (KKG) seluruh sfat yang diamati

\begin{tabular}{lcccc}
\hline \multicolumn{1}{c}{ Sifat yang diamati } & KKG $(\%)$ & Kriteria & $\mathrm{H}^{2}(\%)$ & Kriteria \\
\hline Umur keluar malai & 10.13 & Sedang & 97.00 & Tinggi \\
Umur keluar rambut tongkol & 9.41 & Sedang & 95.64 & Tinggi \\
Selisih umur keluar rambut tongkol dengan & 29.55 & Tinggi & 30.00 & Sedang \\
keluar malai (ASI) & & & & \\
Umur panen & 8.07 & Sedang & 90.05 & Tinggi \\
Sudut daun & 4.81 & Rendah & 8.48 & Rendah \\
Tinggi tanaman & 3.31 & Rendah & 10.56 & Rendah \\
Jumlah daun per tanaman & 8.73 & Sedang & 56.94 & Tinggi \\
Diameter batang & 8.34 & Sedang & 27.35 & Sedang \\
Jumlah daun segar saat panen per tanaman & 14.20 & Sedang & 43.17 & Sedang \\
Bobot brangkasan segar per tanaman & 14.29 & Sedang & 35.77 & Sedang \\
Bobot tongkol kering panen per tanaman & 11.09 & Sedang & 29.11 & Sedang \\
Panjang tongkol & 4.15 & Rendah & 19.50 & Rendah \\
Diameter tongkol & 4.40 & Rendah & 44.00 & Sedang \\
Daya hasil (bobot biji kering pipil per plot) & 22.53 & Tinggi & 70.69 & Tinggi \\
Bobot 1.000 butir biji & 14.14 & Sedang & 76.05 & Tinggi \\
\hline
\end{tabular}


Pada Tabel 5 terlihat pula, nilai heritabilitas arti luas tergolong tinggi diperoleh pada sifat umur keluar malai, umur keluar rambut tongkol, umur panen, jumlah daun per tanaman, daya hasil (bobot biji kering pipil per plot) dan bobot 1.000 butir bij. Sudut daun, tinggi tanaman dan panjang tongkol memiliki heritabilitas arti luas tergolong rendah. Sifat yang memiliki heritabilitas tergolong sedang, yaitu ASI, diameter batang, jumlah daun segar saat panen per tanaman bobot brangkasan segar per tanaman, bobot tongkol kering panen per tanaman dan diameter tongkol. Heritabilitas merupakan perbandingan ragam genetik terhadap ragam fenotip. Apabila ragam genetik total yang diperhitungkan, maka disebut heritabilitas arti luas $\left(\mathrm{H}^{2}\right)$; sedangkan apabila hanya memperhitungkan ragam aditif, maka akan diperoleh heritabilitas arti sempit $\left(\mathrm{h}^{2}\right)$. Dalam penelitian ini heritabilitas arti luas yang tergolong tinggi diperoleh pada umur keluar malai, umur keluar rambut tongkol, umur panen, Jumlah daun per tanaman, daya hasil dan bobot 1.000 butir biji. Sifat-sifat tersebut, dapat diperbaiki dengan seleksi massa dan dilakukan pada siklus awal. Hal ini sesuai dengan pendapat Basuki (2005), bahwa sifat dengan heritabilitas tinggi, maka perbaikan sifat tersebut dapat dilakukan dengan seleksi massa. Robby (2019) dan Iqra (2019) juga memperoleh nilai heritabilitas arti luas yang tergolong tinggi pada daya hasil berturut turut sebesar $60.32 \%$ dan $56.41 \%$. Sudut daun memiliki nilai heritabilitas arti luas rendah dan keragaman genetik sempit. Sifat ini tidak membutuhkan perbaikan melalui seleksi karena galur-galur F2 yang diuji dan terpilih sudah memiliki sudut daun sempit sama dengan sudut daun hibrida komersial.

\section{KESIMPULAN}

Galur F2 P8IS x T1NK7328 (R16), F2 P8IS x T1NK7328 (R18), dan galur F2 P8IS x NK212 (R4), memiliki sudut daun tergolong sama dengan masing-masing tetua turunan pertama hibrida/hibrida (T1NK7328 dan NK212) dan lebih kecil dibanding P8IS. Umur panen ketiga galur F2 tersebut tergolong super genjah. Daya hasil (bobot biji kering pipil per plot) galur F2 P8IS x T1NK7328 (R16), F2 P8IS x T1NK7328 (R18), sama dengan kedua tetua; sedangkan galur F2 P8IS x NK212 (R4), daya hasilnya hanya lebih tinggi dibanding Sinta Unram. Daya hasil memiliki nilai koefisien keragaman genetik tergolong tinggi; umur panen sedang dan sudut daun tergolong rendah. Heritabilitas arti luas tergolong tinggi diperoleh pada umur panen dan daya hasil; sedangkan sudut daun tergolong rendah. Galur F2 P8IS x T1NK7328 (R16), F2 P8IS x T1NK7328 (R18), dan galur F2 P8IS x NK212 (R4), dapat digunakan sebagai bahan populasi dasar untuk membentuk varietas unggul jagung dengan sudut daun kecil dan umur panen super genjah dan hasil lebih tinggi dibanding Sinta Unram.

\section{Ucapan Terimakasih}

Tim penelitian mengucapkan terima kasih yang sebesar-besarnya atas dana yang telah diberikan, sehingga penelitian ini dapat diselesaikan. Tim juga mengucapkan terima kasih kepada Ketua dan staf LPPM Unram atas bantuan administrasi, sehingga proses dapat berjalan dengan lancar. 


\section{DAFTAR PUSTAKA}

Abdalla A., Mahmoud M. F. and Naim A. M. E. 2010. Evaluation of Some Maize (Zea mays L.) Varieties in Different Enviromnents of The Nuba Mountain, Sudan. Australian Journal of Basic and Applied Sciences, 4 (12): 6605 - 6610.

Azrai M. 2013. Jagung Hibrida Genjah: Prospek Pengembangan Menghadapi Perubahan Iklim. IPTEK TANAMAN PANGAN Vol. 8 No. 2. Hal. 90 - 96.

Balitbangtan. 2004. Panduan Karakterisasi Tanaman Jagung. Hal. 1-26. Dalam. Panduan Karakterisasi Tanaman Pangan: Jagung \&Sorgum.. Departemen pertanian, Badan Penelitian dan Pengembangan Pertanian Komisi Nasional Plasma Nutfah, Bogor.

Basuki N. 2005. Genetika Kuantitatif. Fakultas Pertanian Universitas Brawijaya, Malang.

Dahlan M. M. dan S. Slamet. 1992. Pemuliaan Tanaman Jagung. Hal. 17 - 38. Dalam: A. Kasno, M. Dahlan dan Hasnam. Proseding Simposium Pemuliaan Tanaman I. PPTI Jawa Timur.

Ishaq M., H. Rahman, G. Hassan, M. Iqbal, I.A. Khalil, S.A Kha, S.A Khan, Rafiulluh, and J. Hussain. 2015. Genetic Potential, Variability and Heritability of Variouns Morphological and Yield Traits Among Maize Synthetics. Electronic Journal of Biology. 11(4):187-191.

Istiningrum P., dan Damanhuri. 2016. Keragaman dan Heritabilitas Sembilan Genotip Tomat (Lypersicum esculentum Mill.) pada Budidaya Organik. Jurnal Agroekotek 2: 70-81.

Iqra P.A. 2019. Kemajuan seleksi massa secara tidak langsung hingga siklus kedelapan terhadap daya hasil tanaman jagung (Zea mays L.) Di lahan kering. [Skripsi, unpublished]. Budidaya Pertanian, Fakultas Pertanian, Universitas Mataram. Mataram, Indonesia.

Jaya D., Sudirman and Sudika I W. 2019. Light interception and yield of some maize varieties grown in a double-row pattern under different urea applications. IOP Conf. Series: Earth and Environmental Science

346: 1-6.

Kusnarta I G M dan Sudika I W., 2018. Pengujian Daya Hasil Beberapa Varietas Tanaman Jagung pada Kondisi Cekaman Kekeringan yang Diberi Pupuk Kandang di Lahan Kering Lombok Utara. Jurnal Sain Teknologi dan Lingkungan (JSTL) Vol 4 (1): 43 53.

Lupi C. 1995. Genetic Engineering for Plant Protection Methods, State of the Art and Applications. $\quad$ http://www.bats.ch/bats/publikationen/1995-1_TA/2methods.php?lang_select=de (Diakses, 19 Januari 2019).

Nugroho B. dan P. B. Gayuh. 2014. Keragaan Tanaman Jagung Lokal Srowot Banyumas Karena Pengaruh Selfing Pada Generasi F2 Selfing. Prosiding Seminar Hasil LPPM UMP: 20-24.

Reif J.C., F.M. Gumpert, S. Fisher and A.E. Melchinger. 2007. Kuantitative Genetics (Abst). Genetics, 176 (3): 294.

Robby D. P. 2019. Kajian Kemajuan Seleksi Indeks Siklus Ketujuh Pada Tanaman Jagung di Lahan Kering. [Skripsi, unpublished]. Budidaya Pertanian, Fakultas Pertanian, Universitas Mataram. Mataram, Indonesia. 
Romadhona R.F, Basunanda P, Murti R.H. 2014. Perbandingan kemajuan genetis seleksi massa dan tongkol-ke-baris pada populasi generasi ketiga persarian bebas jagung hibrida. Vegetalika. 3(2): 72-84.

Shahrockhi M., S.K. Khorasani and A. Ebrahimi. 2013. Study of Genetic Components in Various Maize (Zea mays L.) Traits, Using Generation Mean Analysis Method. International Journal of Agronomy and Plant Production, 4 (3): 405 - 412.

Sudika I W. 2015. Kajian Potensi Hasil, Ketahanan Cekaman Kekeringan dan Umur Panen Hasil Hibridisasi pada Tanaman Jagung (Zea mays L.) Di Lahan Kering (Disertasi). Program studi ilmu pertanian Program Pascasarjana Universitas Brawijaya, M a 1 a n g.

Sudika I W., Arya Parwata dan Soemeinaboedhy. 2018. Respon Seleksi Massa Secara Tidak Langsung Terhadap Daya Hasil Tanaman Jagung Selama Tujuh Siklus Di Lahan Kering. Jurnal Sain Teknologi dan Lingkungan (JSTL) Vol 4 (2): 144 - 152.

Sudika I W. , Soemeinaboedhy.dan A. Parwata. 2019. Seleksi massa guna memperoleh varietas unggul jagung tahan kering, umur panen super genjah, Hasil dan brangkasan segar tinggi. Laporan Hasil Penelitian Tahun ketiga (Unpublish). Lembaga Penelitian dan Pengabdian Kepada Masyarakat Universitas Mataram, Mataram

Sudika dan D. R. Anugrahwati. 2020. Perbaikan Sudut Daun Populasi Komposit Tanaman Jagung Melalui Hibridisasi Dengan Varietas Hibrida. Makalah disampaikan pada Seminar Nasional Saintek LPPM Unram.

Syukur M., Sujiprihati S., Yunianti R. 2012. Teknik Pemuliaan Tanaman. Penebar Swadaya. Depok.

Wannows A.A., H.K. Azzam and S. A.Al-Ahmad. 2010. Genetic Variances, Heritability, Correlation and Path Coefficient Analysis in Yellow Maize Crosses (Zea mays L.). Agriculture and Biology Journal of North America, 1 (4): 630 - 637.

Wardyn B.M., J.W. Edwards and K.R. Lamkey. 2007. The Genetic Structure of a Maize Population: The Role of Dominance. Crop Sci. 47: 467 - 476. doi: 10.2135/cropsci.2006.05.0294.

Ujianto, L., Muliarta, A, A.A. Sudharmawan dan I W. Sudika, 2020. Teknik Analisis dan Rancangan Persilangan (Buku Ajar). Mataram University Press, Mataram.

Yulisma. 2011. Pertumbuhan dan Hasil Beberapa Varietas Jagung pada Berbagai Jarak Tanam. Penelitian Petanian Tanaman Pangan.Vol 3 (2) :196-203.

Yunandra, Syukur M, dan Maharijaya A. 2017. seleksi dan kemajuan seleksi komponen hasil pada persilangan cabai keriting dan cabai besar. Jurnal Agron Indonesia. 45(2): $170 \square 175$. https:// doi.org/10.24831/jai.v45i2.12312. 